\title{
Phytoprotection
}

\section{Characterization of a monoclonal antibody to turnip mosaic virus and its use in immunodiagnosis of infection}

\section{P. Horsewood, M.R. McDermott, L.W. Stobbs, P.L.J. Brais et B.J. Underdown}

Volume 72, numéro 2, 1991

URI : https://id.erudit.org/iderudit/706004ar

DOI : https://doi.org/10.7202/706004ar

Aller au sommaire du numéro

Éditeur(s)

Société de protection des plantes du Québec (SPPQ)l

ISSN

0031-9511 (imprimé)

1710-1603 (numérique)

Découvrir la revue

Citer cet article

Horsewood, P., McDermott, M., Stobbs, L., Brais, P. \& Underdown, B. (1991).

Characterization of a monoclonal antibody to turnip mosaic virus and its use in immunodiagnosis of infection. Phytoprotection, 72(2), 61-68.

https://doi.org/10.7202/706004ar
Résumé de l'article

Des anticorps monoclonaux spécifiques au virus de la mosaïque du panais (TuMV) ont été produits et utilisés dans un bioessai en sandwich à double anticorps afin de détecter des virus dans des plantes infectées. Un anticorps particulier d'un clone hybridome ayant les caractéristiques recherchées de croissance, de spécificité et de production d'anticorps a été décrit. Cet anticorps a été montré par microscopie électronique immunocytochimique and par immunodétection en point comme réagissant avec une protéine d'enrobage d'un virion. Les conditions procurant une extraction efficace du virus à partir des feuilles ont été étudiées par l'utilisation de l'anticorps dans les étapes de capture et de détection du bioessai en sandwich. Avec un système de tampons d'extraction contenant plusieurs détergents, un essai très sensible a été produit qui détecte des virus de façon fiable dans les plantes infectées. Cet essai est maintenant utilisé de façon routinière pour l'immunodiagnostic des infections causées par le virus de la mosaïque du panais. 


\title{
Characterization of a monoclonal antibody to turnip mosaic virus and its use in immunodiagnosis of infection
}

\author{
P. Horsewood, M.R. McDermott \\ Department of Pathology, McMaster University, \\ Hamilton, Ontario, Canada L8N $3 Z 5$
}

\author{
L.W. Stobbs \\ Agriculture Canada, Research Station, \\ Vineland Station, Ontario, Canada LOR 2EO \\ P.L.J. Brais, and B.J. Underdown \\ Department of Pathology, McMaster University, \\ Hamilton, Ontario, Canada L8N $3 Z 5$
}

(Received 1991-01-15; accepted 1991-08-06)

\begin{abstract}
Monoclonal antibodies specific for turnip mosaic virus (TuMV) were produced and used in a double antibody sandwich enzyme immunoassay to detect virus in infected plants. One particular antibody from a hybridoma clone having desirable growth, specificity and antibody production properties was characterized in detail. This antibody was shown by immunocytochemical electron microscopy and immunoblotting to react with a virion coat protein. Conditions providing efficient extraction of virus from leaves were investigated by using the antibody in both capture and detection steps of a sandwich immunoassay. With an extraction buffer system containing multiple detergents, a highly sensitive assay was produced that reliably detected virus in infected plants. This assay is now in routine use for immunodiagnosis of turnip mosaic virus infections.
\end{abstract}

Horsewood, P., M.R. McDermott, L.W. Stobbs, P.L.J. Brais, and B.J. Underdown. 1991. Characterization of a monoclonal antibody to turnip mosaic virus and its use in immunodiagnosis of infection. PHYTOPROTECTION 72: 61-68.

Des anticorps monoclonaux spécifiques au virus de la mosaïque du panais (TuMV) ont été produits et utilisés dans un bioessai en sandwich à double anticorps afin de détecter des virus dans des plantes infectées. Un anticorps particulier d'un clone hybridome ayant les caractéristiques recherchées de croissance, de spécificité et de production d'anticorps a été décrit. Cet anticorps a été montré par microscopie électronique immunocytochimique and par immunodétection en point comme réagissant avec une protéine d'enrobage d'un virion. Les conditions procurant une extraction efficace du virus à partir des feuilles ont été étudiées par l'utilisation de l'anticorps dans les étapes de capture et de détection du bioessai en sandwich. Avec un système de tampons d'extraction contenant plusieurs détergents, un essai très sensible a été produit qui détecte des virus de façon fiable dans les plantes infectées. Cet essai est maintenant utilisé de façon routinière pour l'immunodiagnostic des infections causées par le virus de la mosaïque du panais.

\section{Introduction}

Turnip mosaic virus is an aphid-transmissible member of the potyvirus group and causes major economic damage in cruciferous crops. The recent introduction of winter canola (Brassica napus ssp. oleifera [Metzg.] Sinsk.) into southern Ontario resulted in increased incidences of TuMV not only in rutabaga $(B$. napus L. ssp. rapifera [Metzg.] Sinsk.), in which losses have reached $50 \%$, but also in other cruciferous crops. In 1985, following a rapid increase in acreage of winter canola, severe production losses occurred in the rutabaga crop in southwestern Ontario. Within 2 years, losses from TuMV were apparent in oriental vegetables grown in outlying areas. Thus, a need arose for recommendations to control and minimize losses from TuMV.

Critical to these recommendations was a need for an effective, rapid diagnostic technique to identify TuMV in plant material and to assess the impact of the virus on commercially-grown crops. At present, field diagnosis of TuMV infection is based on visual symptoms, which are highly variable depending on 
the growth stage at which the plant was infected (unpublished data). Both differences in cultivar susceptibility and environmental conditions influence symptom expression and make visual diagnosis unreliable.

Immunochemical detection of TuMV by enzyme immunoassay (EIA) using conventional rabbit anti-TuMV antiserum obtained from several sources (Plant Virus and Antiserum Bank, Agriculture Canada, Vancouver, British Columbia, Canada; Agriculture Canada, Vineland Research Station, Ontario) was variable; the quality, titre and reproducibility of available antisera were inconsistent. All antisera exhibited relatively high non-specific binding in EIA which probably resulted from contaminating antibody activity to host plant protein. The resulting background measurements compromised the attainable sensitivity of an assay and the detection of low level infections.

Monoclonal antibodies offered a solution to many of these problems by allowing a continuous supply of well-defined, high titred antibodies without cross-reactivity against plant material. Immunoassays using monoclonal antibodies for the detection and characterization of plant viruses have become an important tool in plant pathology (Halk and DeBoer 1985).

This paper describes the preparation and characterization of monoclonal antibodies to TuMV and their use for detection of virus in infected plant material.

\section{Materials and methods}

Virus propagation and isolation. The common Ontario isolate of TuMV (Stobbs and Shattuck 1989) was maintained in systemically-infected rutabaga (Brassica napus ssp. rapifer a cv. Laurentien). Control plants were maintained in a separate growth room and care was taken to avoid any cross-infection. Virus was extracted from leaf material using the procedure described by Choi et al. (1977) as modified by Stobbs and Van Schagen (1987) to reduce particle aggregation. Virus was purified by rate-zonal densitygradient centrifugation at $61000 \mathrm{~g}$ for 120 $\min$ in $5,15,25$ and $35 \%$ sucrose in $50 \mathrm{mM}$ potassium phosphate buffer containing 0.5 $\mathrm{M}$ urea, $\mathrm{pH}$ 7.5. Purified virus was stored at $-20^{\circ} \mathrm{C}$ and protein was determined using the Bio-Rad Protein Assay (Bio-Rad, Richmond, CA).

Monoclonal antibody preparation. $\mathrm{Pu}$ rified virus was injected intra-peritoneally (40 $\mu \mathrm{g} /$ mouse) into Balb/c mice every three weeks. Three days after the third boost, spleen cells were prepared and fused in 1:1 ratio with $\mathrm{sp} 2 / 0$ plasmacytoma cells with $50 \%$ polyethylene glycol (PEG) 4000 (GIB$\mathrm{CO}$, Burlington, Ontario) using the procedure of Galfre et al. (1977). Resulting hybridomas were grown in hypoxanthine, aminopterin, and thymidine (HAT) selective media (GIBCO, Burlington, Ontario) in 96 well plates. Supernatants were assayed shortly after the appearance of visible colonies (6-8 days post-fusion) as described below.

Purified virus $\left(100 \mu \mathrm{L}\right.$ at $5 \mu \mathrm{g} / \mathrm{mL}$ in $\mathrm{CO}_{3} /$ $\mathrm{HCO}_{3}$ buffer, $\mathrm{pH}$ 9.6) was immobilized to the wells of enzyme immunoassay (EIA) plates (Nunc-immunoplate, Maxisorb, GIB$\mathrm{CO}$, Burlington, Ontario) by overnight incubation at $4^{\circ} \mathrm{C}$. Unbound virus was removed by three washes with saline, containing $0.05 \%$ Tween $80(\mathrm{~s} / \mathrm{t})$ and $100 \mu \mathrm{L}$ culture supernatants were added for $\mathrm{lh}$ at room temperature. The supernatants were removed. the wells washed three times with $\mathrm{s} / \mathrm{t}$ and bound antibodies were detected with alkaline-phosphatase conjugated goat anti-mouse immunoglobulin $(\mathrm{H}+\mathrm{L}$ chain specific) (Jackson Laboratories, Bar Harbor, ME) followed by the addition of $p$-nitrophenyl phosphate substrate (Sigma, St. Louis, MO). Normal mouse serum was used at a dilution of 1:200 as a negative control and immune mouse serum at a dilution of 1:2000 as a positive control. Hybridomas whose culture supernatants were strongly positive were cloned twice by limiting dilution. Ascites fluid, induced by intraperitoneally injected cells from clone $7 \mathrm{~B}$, was used for immunoblotting, immunogold decoration and preparation of immunoglobulin (Ig) for enzyme conjugation.

Immunoblotting. Purified virus, infected, and uninfected plant leaf extracts were subjected to electrophoresis on sodium dodecyl sulfate polyacrylamide gels (SDSPAGE, $7.5 \%-15 \%$ gradient) under reducing and non-reducing conditions, according to the method of Laemmli (1970). The separat- 
ed proteins were electro-transferred to nitrocellulose (Transblot, Bio-Rad, Richmond, CA) using the manufacturers directions. Nitrocellulose blots were blocked with $2 \%$ bovine serum albumin(BSA) in 50 mM Tris containing $0.05 \%$ Tween 80 (Tris/Tween), pH 7.2, for $2 \mathrm{~h}$ and then incubated for $90 \mathrm{~min}$ with ascites fluid (clone 7B) diluted 1:2000 in 1\% BSA in Tris/Tween. Unbound antibody was removed with three 2min washes with Tris/Tween and the blot was then incubated for 90 min with alkaline phosphatase conjugated goat anti-mouse immunoglobulin $(\mathrm{H}+\mathrm{L})$ diluted $1: 1000$ with $1 \% \mathrm{BSA}$ in Tris/Tween. Unbound conjugate was removed by three 2-min washes with Tris/Tween. Bound conjugate was detected with substrate (BRL, Gaithersburg, MD) consisting of $3.3 \mathrm{mg}$ of nitroblue tetrazolium chloride (NBT), 1.65 $\mathrm{mg}$ of 5-bromo-4-chloro-3-indolyl phosphate $p$-toluidine salt (BCIP), dissolved in $20 \mathrm{~mL}$ of $100 \mathrm{mM}$ Tris buffer, $\mathrm{pH}$ 9.6, containing $2 \mathrm{mM}$ $\mathrm{MgCl}_{2}$.

Immunogold decoration. The methodology was that of Beesley and Betts (1987) with some modifications. All incubations and washing procedures were conducted at room temperature by floating specimen grids on reagent droplets placed on Parafilm; grids were never allowed to dry throughout the procedure (Bendayan 1984). Collodion/carbon-coated nickel grids were floated on a suspension of $40 \mu \mathrm{g} / \mathrm{mL}$ TuMV in distilled water for $30 \mathrm{~min}$. Unbound virus was removed by washing with distilled water for $10 \mathrm{~min}$ and the grids were then blocked for $10 \mathrm{~min}$ with $10 \mathrm{~mL}$ sodium phosphate buffered saline (PBS), pH 7.2, containing 1\% BSA. The virus-coated grids were washed in distilled water for $10 \mathrm{~min}$ and then incubated for $2 \mathrm{~h}$ with the purified immunoglobulin fraction $(38 \mu \mathrm{g} / \mathrm{mL})$ of clone $7 \mathrm{~B}$ ascites fluid diluted in $0.5 \%$ BSA/PBS. Excess antibody was washed off with PBS for $10 \mathrm{~min}$, and after blocking in $1 \% \mathrm{BSA} / \mathrm{PBS}$ for $10 \mathrm{~min}$, the grids were incubated for $60 \mathrm{~min}$ with rabbit anti-mouse $\mathrm{Ig}$ (Dakopatts, Dimension Laboratories, Inc., Mississauga, Ontario) diluted $1: 25$ in $0.5 \%$ BSA/PBS. Unbound rabbit antibodies were washed off with PBS for 10 min and grids were incubated for 30 min with Protein A-gold complex (Protein AG 10, EM grade, Janssen Pharmaceutica, S.P.I. Supplies, Toronto, Ontario) diluted 1:30 in PBS. The grids were washed for $10 \mathrm{~min}$ in PBS and negatively stained for $5 \mathrm{~min}$ using $2 \%$ phosphotungstic acid. Excess stain was removed; the grids were dried and examined with a Philips 301 transmission electron microscope operated at $60 \mathrm{KV}$.

\section{Alkaline phosphatase conjugation.} Ascites fluid (clone 7B) containing monoclonal anti-TuMV was chromatographed on Protein A-Sepharose (Pharmacia, Montreal, Quebec) to yield a purified immunoglobulin fraction. The immunoglobulin and alkaline phosphatase (Scripps Laboratories, San Diego, CA) in a 1:3 ratio by weight were coupled with glutaraldehyde at a final concentration of $0.6 \%$ and aliquots were removed at $0,1,2,5,30$ and $60 \mathrm{~min}$. The reaction was stopped with $50 \mathrm{mM}$ Tris, $\mathrm{pH} 8.0$, containing $5 \%$ ovalbumin and $1 \mathrm{mM} \mathrm{MgCl}_{2}$. After overnight dialysis against PBS, the various conjugates were each titred against purified TuMV bound to wells of microtitre plates. The optimal conjugation time was chosen and used for further conjugate preparations. Stock conjugate was stored in sterile aliquots at $4^{\circ} \mathrm{C}$.

Preparation of plant extract. Leaves from infected or uninfected plants were flash frozen by immersion in liquid nitrogen and then pulverized using a mortar and pestle pre-cooled in liquid nitrogen. The powdered leaves were extracted with $50 \mathrm{mM}$ Tris buffered saline, $\mathrm{pH} 7.2$, containing $0.1 \%$ sodium dodecyl sulphate, $1 \%$ sodium deoxycholate, $1 \%$ Triton X100 and 0.13 trypsin inhibitor units/mL aprotinin (RIPA buffer) and filtered through cheesecloth. Nineteen milliliter of extraction buffer were used for each gram of fresh leaves. Particulate material was sedimented by centrifugation at $2700 \mathrm{~g}$ for $10 \mathrm{~min}$ and the supernatant was stored at $4^{\circ} \mathrm{C}$ for future use.

Enzyme immunoassay. The direct-double-antibody sandwich ELISA, as described by Clark and Adams (1977) was used with several modifications. All tests were done in Nunc plates (Gibco) with $100 \mu \mathrm{L}$ of reagent used for each of the steps. Anti-TuMV immunoglobulin, prepared from ascites fluid using caprylic acid/ammonium sulphate precipitation (McKinney and Parkinson 1987), was bound to the wells in $50 \mathrm{mM}$ sodium carbonate buffer, $\mathrm{pH} 9.6$, at $5 \mu \mathrm{g} / \mathrm{mL}$ for $2 \mathrm{~h}$ at $37^{\circ} \mathrm{C}$. Wells were washed three times with $\mathrm{s} / \mathrm{t}$ and then blocked for $30 \mathrm{~min}$ at $37^{\circ} \mathrm{C}$ with $50 \mathrm{mM}$ Tris-buffered saline, $\mathrm{pH} 7.6$, containing $0.1 \% \mathrm{BSA}$ and 
$0.02 \%$ sodium azide (reagent buffer). After three washing steps with $s / t$, the plant extract was added to the wells in RIPA buffer and incubated for $60 \mathrm{~min}$ at $37^{\circ} \mathrm{C}$. The excess extract was removed and the wells were washed three times with s/t. Alkaline phosphatase conjugated anti-TuMV diluted to $150 \mathrm{ng}$ antibody $/ \mathrm{mL}$ in reagent buffer was then added for $60 \mathrm{~min}$ at $37^{\circ} \mathrm{C}$. The conjugate was removed and the wells were washed three times with s/t. Finally, $p$-nitrophenyl phosphate substrate, diluted to $1 \mathrm{mg} / \mathrm{mL}$ in 1 Mdiethanolamine, $\mathrm{pH} 9.8$, containing $0.5 \mathrm{mM} \mathrm{MgCl}_{2}\left(30 \mathrm{~min}, 37^{\circ} \mathrm{C}\right)$ was added. Optical density (OD) readings at $405 \mathrm{~nm}$ were measured after stopping the reaction with $50 \mu \mathrm{L}$ of $2 \mathrm{M}$ sodium hydroxide solution. Plants were considered positive for virus infection if they gave OD readings greater than two standard deviations (2 SD) above the mean OD found for uninfected, control leaves.

\section{Results}

Monoclonal antibody screening and selection. Using the purified virus as target antigen, an enzyme immunoassay (EIA) was developed to detect monoclonal antibodies in hybridoma culture supernatants. The assay was initially validated using sera from immunized mice as positive controls. Subsequently, supernatants showing reactivity equivalent to, or better than, 1:2000 diluted immune sera were chosen for further characterization and investigation. Supernatants from twicecloned hybridomas were assessed for reactivity at various dilutions to obtain a measure of antibody affinity (Van Heyningen et al. 1983). The clones showing the highest affinity were investigated further for development of a virus detection assay. One clone, 7B, had desirable growth and specificity characteristics, produced high affinity antibodies, induced good volumes of ascites, and was used in most of the assay developments.

Immunoblotting. Results from immunoblot detection of SDS-PAGE separated and transferred viral proteins, are shown in Figure 1. Under non-reducing conditions, the monoclonal antibody 7B detected several bands against proteins of purified virus corresponding with molecular weights of $73,66,64,36$ and $34 \mathrm{kDa}$. TuMV-infected leaf extract showed a major band at $34 \mathrm{kDa}$ with a minor band at $36 \mathrm{kDa}$. An additional diffuse, high molecular weight band at $180 \mathrm{kDa}$ was seen in both the infected and uninfected leaf extracts, but not in the proteins from purified virus. A similar pattern for the major bands was seen under reducing conditions except that, in general, bands were sharper and more intense, enabling several smallermolecular weight bands at 31,29, 27 and $25 \mathrm{kDa}$ (Lane d) to be seen for proteins from purified virus. The extract from infected leaves, but not from the uninfected leaves, showed the same doublet band at 36,34 $\mathrm{kDa}$ (Lanes e and $\mathrm{f}$ ) as seen under non-reducing conditions. The patterns seen for the protein bands after Coomassie blue staining of the SDS gels were very similar to those seen on the immunoblots but with some other minor bands present (datanot shown). The reactivity patterns seen with the preparations containing the virus are consistent with the 7B monoclonal antibody having specificity for capsid protein.

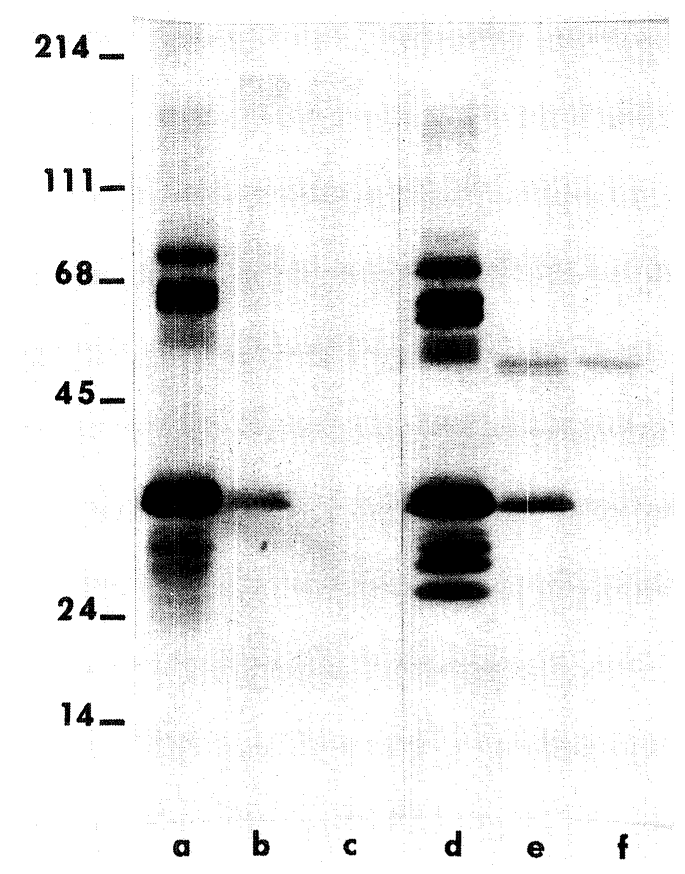

Figure 1. Immunoblot detection of proteins from purified virus (lanes a and d), infected (lanes $b$ and e) and uninfected (lanes $c$ and f) leaf extracts. Proteins were separated by 7.5 - $15 \%$ gradient SDS-PAGE, under nonreducing (lanes a, b and c) and reducing (lanes $\mathrm{d}$, e and $\mathrm{f}$ ) conditions and electrotransferred to nitrocellulose. Blots were overlaid with $7 \mathrm{~B}$ monoclonal antibody and bound antibody was detected with rabbit anti-mouse $\operatorname{IgG}(\mathrm{H}+\mathrm{L})$ alkaline phosphatase conjugate. Molecular weight markers (kDa) are indicated. 
Immunogold decoration. Electron microscopic examination of the purified virus after indirect immunodecoration with colloidal gold showed filamentous particles specifically and uniformly labelled along their length (Fig. 2). The labelling configuration is suggestive of the monoclonal antibody binding to the surface of the virion coat protein.

Enzyme immunoassay. The assay was developed using alkaline phosphatase-conjugated monoclonal antibody (7B-AP) with a variety of monoclonal capture antibodies. Of the various monoclonal antibodies tested for use in the capture step, no real advantage was shown by any monoclonal antibodies. Using the same monoclonal (7B) in the capture layer as used in the detection step (7B-AP) was equally as sensitive as using other capture antibodies. Because of the advantages of producing $7 \mathrm{~B}$ ascites fluid compared to the

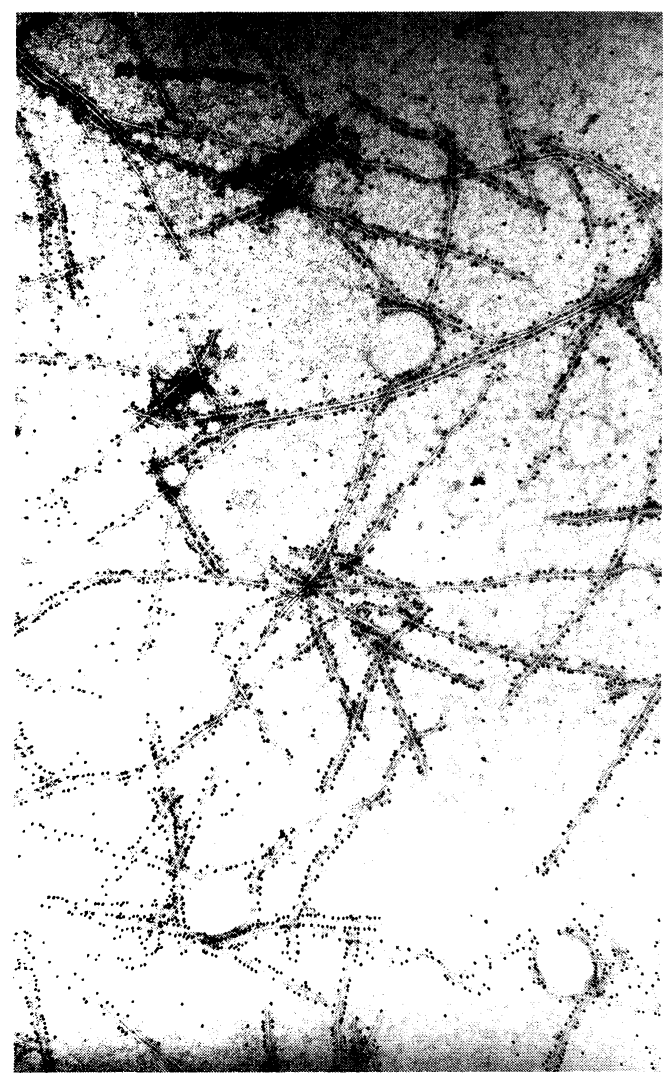

Figure 2. Immunogold decoration of TuMV. Electron micrograph of purified TuMV incubated with antibody $7 \mathrm{~B}$ followed by rabbit anti-mouse Ig and Protein-A-gold complex. other monoclonal antibodies, this reagent was used in all further developments in both the capture and detection steps. Detection of purified virus with this combination was in the low ng/mL range (Fig. 3). The assay showed no specificity for tobacco mosaic virus which was used as a negative control and virus was not detected when normal mouse serum was used in place of the monoclonal capture antibody (data not shown).

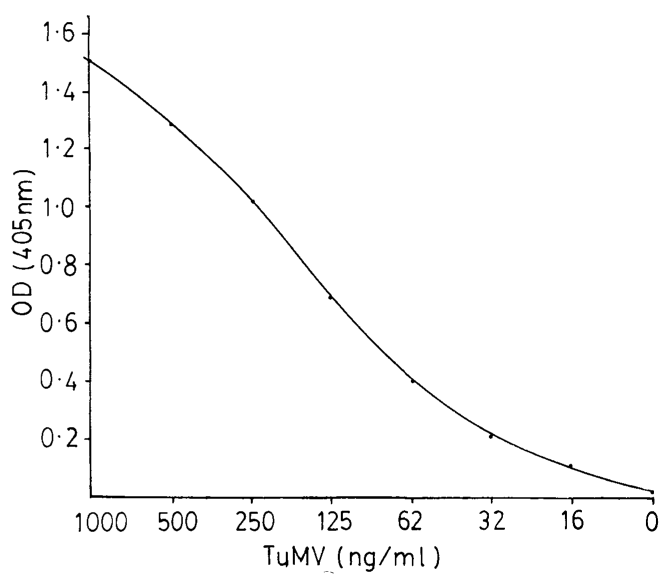

Figure 3. Assay of purified TuMV by sandwich EIA. Using immobilized monoclonal 7B-antibody in the capture layer and alkaline phosphataseconjugated 7B-antibody as detector, low levels of virus were detected.

Plant extract, prepared by triturating TuMV-infected leaves with neutral phosphate buffer, was tested in the assay, but very little virus was detected. Similarly, when purified virus was diluted in uninfected plant extract, little or no virus was detected. The interference of the extract limited the sensitivity and utility of the assay and this was further investigated. Addition of uninfected plant extract, either before or after adding purified virus in buffer to the capture layer, had little effect on the assay. Thus, the extract itself neither caused blocking of the capture antibody nor caused blocking of detection of the bound virus by antibody conjugate.

The results indicated that the virus availability in the extract may be limited either through degradation or binding to extract components. Inclusion of phenylmethanesulphonyl fluoride, a protease inhibitor, in the extraction buffer did not improve virus detection. 
Similarly, neither centrifugal removal of fine particulate matter, nor heat inactivation $\left(60^{\circ} \mathrm{C}\right.$, $30 \mathrm{~min}$ ) improved sensitivity. The latter re-

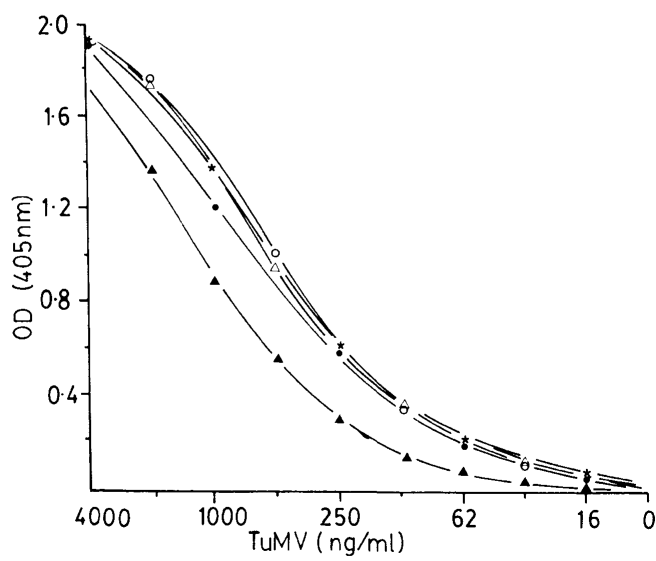

Figure 4. Testing of extraction buffers on TuMV virus availability in a sandwich EIA. Purified virus was assayed after dilution in leaf extract obtained using the following buffers: a) reagent diluent (50 $\mathrm{mM}$ Tris buffered saline with $0.02 \%$, sodium azide and $0.1 \% \mathrm{BSA}$, $\mathrm{pH} 7.6), \boldsymbol{\Delta}$; b) RIPA buffer without sodium deoxycholate, ;c) RIPA buffer, $*$; d) RIPA buffer without Triton X-100, $\triangle$; e) RIPA buffer without SDS, $\bigcirc$. sulted in precipitate formation with a subsequent complete lack of virus detection.

Investigation of various buffers was carried out to determine suitable conditions for plant extraction that would make virus more available and which would not interfere with virus detection. Freezing of plant leaves in liquid nitrogen and trituration using a cooled mortar and pestle produced a fine powder that was more efficiently extracted. Testing of extraction buffers on powdered leaves and using the resulting extract as a diluent for purified virus showed that buffers containing detergents were most effective (Fig. 4). A multidetergent buffer (RIPA buffer) proved efficient in extracting virus antigen from plant material and showed no deleterious effects in the assay. Using this buffer in the virus detection assay provided excellent discrimination between infected and non-infected plant material (Fig. 5). This assay is now in routine use for screening crops for TuMV infection.

\section{Discussion}

Immunoelectron microscopy indicated that monoclonal antibody 7B had specificity for a capsid protein. Further evidence for the capsid protein specificity of the monoclonal

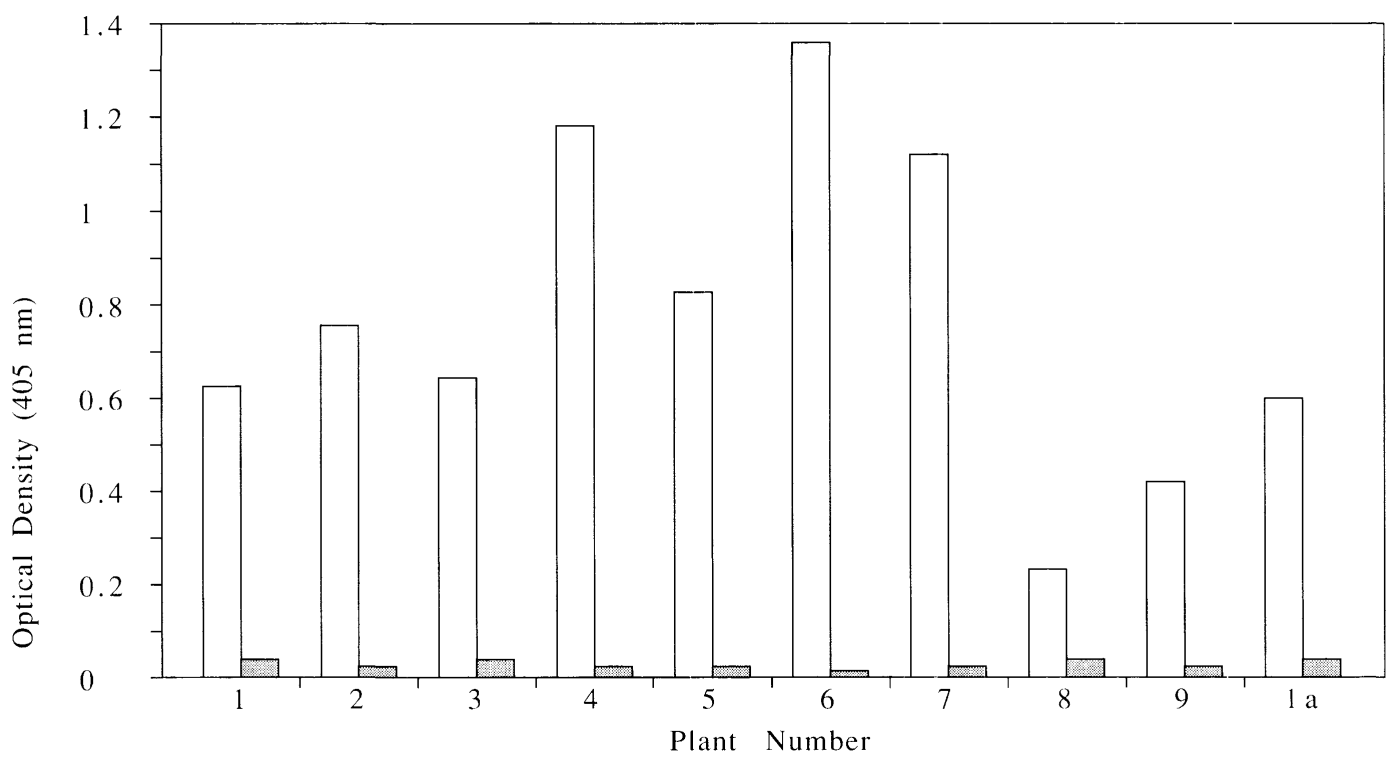

Figure 5. Assay of TuMV infected and non-infected leaf extract of rutabaga. Leaves from nine infected or non-infected plants were extracted with RIPA buffer and assayed. Two different leaves (I and la) from plant 1 were chosen and assayed. Results for infected leaves are shown as open bars and for noninfected leaves as shaded bars. 
antibody was seen on immunoblotting. The antibody reacted against proteins from the purified virus and from infected plant extract which appeared as a doublet with molecular weights corresponding to 36 and $34 \mathrm{kDa}$. Additional bands were seen, which were most evident under reducing conditions. Hiebert and McDonald (1973) reported on the characterization of proteins associated with viruses of the potato $Y$ group and indicated a slow form of the TuMV coat protein which gradually converts to a faster form upon prolonged storage, especially with partially purified preparations. These same authors in a later investigation reported slow, intermediate and fast forms for capsid protein, with molecular weights of 36,29 and $27 \mathrm{kDa}$, respectively.

Bands corresponding to possible intermediate and fast forms of the $36-34 \mathrm{kDa}$ doublet were evident on the immunoblot of the purified virus proteins but none were seen for the extract of virus-infected rutabaga leaves. The additional higher molecular weight bands in the $60 \mathrm{kDa}$ region seen with the purified virus may represent either dimeric capsid proteins or other cross-reactive viral proteins. The former possibility has also been considered by Aebig et al. (1987) in an analysis of Western blot results with a monoclonal antibody against prunus necrotic ringspot ilarvirus. Cytoplasmic inclusion proteins of TuMV, with a reported molecular weight of $70 \mathrm{kDa}$, have been shown to be immunologically non-cross-reactive with capsid proteins (Purcifull et al. 1973). Minor bands at $180 \mathrm{kDa}$ and approximately $50 \mathrm{kDa}$ were seen under non-reducing and reducing conditions, respectively. These bands were seen with infected and non-infected plant extracts, but not with purified virus and could represent possible endogenous plant proteins with phosphatase activity.

The enzyme immunoassay for detection of virus was developed in a step-wise manner. Mixtures of several monoclonal antibodies showed no advantage over individual components probably due to the antibodies showing specificity to the same or spatially closely orientated capsomer epitopes. Since there are many copies of each of these epitopes on the whole capsid, there may be a limiting, saturable number of antibody molecules that can bind per capsid and hence, no advantage in using certain mixtures. Similarly, the fact that no advantage was seen in using a capture antibody different from that used as detecting antibody may reflect the same multideterminant nature of the epitope on the virus. Using a solid phase radioimmunoassay, Hill et al. (1984) found that for diagnosis of soybean mosaic virus, an assay using the same monoclonal antibody for coating and tritium labelling, lacked sensitivity compared to a combination using different epitope specific monoclonal antibodies for capture and detection. However, the nature of the specific binding site of the monoclonal antibody used in the single antibody assay was not reported and may have been against an infrequent determinant.

Taken together with the information from virus particle immunodecoration and immunoblotting, it appears likely that the 7B monoclonal antibody had specificity for a readily available, capsomer determinant of the virus and as such would be well suited for a virus detection assay.

Virus detection was greatly increased by employing freeze-fracturing of plant leaves followed by extraction with a buffer containing a mixture of detergents. Buffers containing one or more detergents showed that virus detection was enhanced when both ionic and non-ionic detergents were present. When used together, these two steps enabled virus to be readily detected in infected plants. This is likely attributable to a more efficient recovery of virus from the extracts, possibly through inhibition of aggregation or release of bound virus from plant components both of which could result in virus loss in the preliminary centrifugation step before assay. Yields of purified virus from infected plants are variable and various modifications of extraction buffers to reduce virus aggregation have been used (Hiebert and McDonald 1973). Consistent detection of TuMV inclusion antigens in plant extracts was obtained by Purcifull et al. (1973) only when sodium dodecyl sulphate (SDS) was added to the extracts.

The assay, using the detergent-containing extraction buffer, reliably detected virus in TuMV-infected plants while uninfected plants were consistently negative. Several thousand leaf samples have been tested by this method. The assay reliably detected virus four to five days post infection and this was earlier than visual symptoms appeared (usually around 
day 10). During the course of this testing the monoclonal antibody was shown to react to all six strains of TuMV so far tested and was shown to be non-reactive with several other members of the potyvirus group (Stobbs and Shattuck 1989; Stobbs et al. 1989).

Aebig, J.A., R.L. Jordan, R.H. Lawson, and H.T. Hsu. 1987. Immunochemical and biological properties of a mouse monoclonal antibody reactive to prunus necrotic ringspot ilarvirus. Intervirology 28: 57-64.

Beesley, J.F., and M.P. Betts. 1987. Colloidal gold probes for the identification of virus particles: an appraisal. Micron Microsc. Acta 18: 299-305.

Bendayan, M. 1984. Protein A-gold electron microscopic immunocytochemistry: methods, applications and limitations. J. Electron Microsc. Tech. 1: 243-270.

Choi, J.K., T. Maeda, and A. Wakimoto. 1977. An improved method for purification of Turnip Mosaic Virus. Ann. Phytopathol. Soc. Jpn. 43: 440-448.

Clark, M.F., and A.N. Adams. 1977. Characteristics of the microplate method of enzyme-linked immunosorbent assay for the detection of plant viruses. J. Gen. Virol. 34: 483

Galfre, G., S.C. Howe, C. Milstein, G.W. Butcher, and J.C. Howard. 1977. Antibodies to major histocompatibility antigens produced by hybrid cell lines. Nature 266: 550-552.

Halk, E.L., and S.H. DeBoer. 1985. Monoclonal antibodies in plant disease research. Annu. Rev. Phytopathol. 23: 321-350.
Hiebert, E., and J.G. McDonald. 1973. Characterization of some proteins associated with viruses in the potato Y group. Virology 56: 349-361.

Hill, E.K., J.H. Hill, and D.P. Durand. 1984. Production of monoclonal antibodies to viruses in the potyvirus group: use in radioimmunoassay. J. Gen. Virol. 65: 525-532.

Laemmli, V.K. 1970. Cleavage of structural proteins during the assembly of the head of bacteriophage T4. Nature 227: 680-685.

McKinney, M.M., and A. Parkinson. 1987. A simple, non-chromatographic procedure to purify immunoglobulins from serum and ascites fluid. J. Immunol. Methods 96: 271-278.

Purcifull, D.E., E. Hiebert, and J.G. McDonald. 1973. Immunochemical specificity of cytoplasmic inclusions induced by viruses in the potato $\mathrm{Y}$ group. Virology 55:275-279.

Stobbs, L.W., and J.G. Shattuck. 1989. Turnip mosaic virus strains in southern Ontario. Plant Dis. 73: 208213.

Stobbs, L.W., and J.G. Van Schagen. 1987. Occurrence and characterization of a turnip mosaic virus isolate infecting Alliaria petiolata in Ontario, Canada. Plant Dis. 71: 965-968.

Stobbs, L.W., D. Hume, and B. Forrest. 1989. Survey of canola germplasma for resistance to turnip mosaic virus. Phytoprotection 70: 1-6.

Van Heyningen, V., D.J.H. Brock, and S. Van Heyninger. 1983. A simple method for ranking the affinities of monoclonal antibodies. J. Immunol. Methods 62: 147-153. 